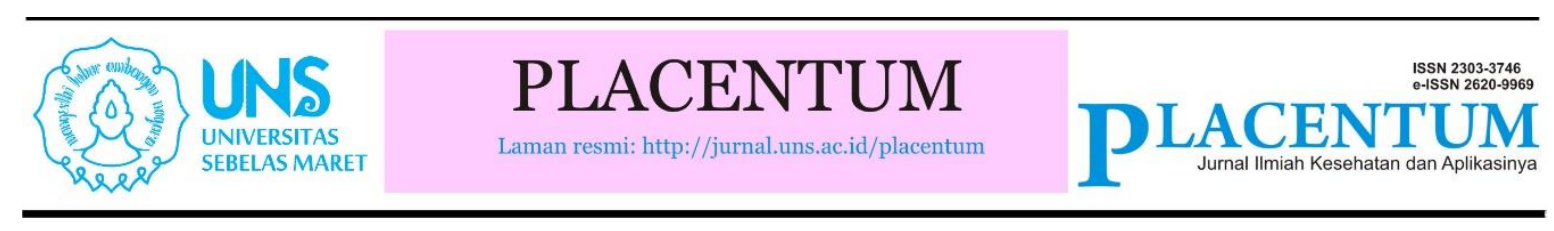

\title{
The Behavior of Women of Reproductive Age In Preconception Care Practices In Surabaya
}

\author{
Yhenti Widjayanti ${ }^{1}$ \\ ${ }^{I}$ Nursing Department, STIKES Katolik St Vincentius a Paulo Surabaya, Jl Jambi 12 Surabaya \\ * Corresponding author \\ E-mail:yhentiwijayanti@gmail.com
}

\begin{abstract}
Preconception care aims to ensure that the mother and her partner are in optimal physical and emotional health status during the onset of pregnancy and to prepare for optimal physical and emotional pregnancy. but most women do not take preconception treatments. The purpose of this study was to identify the behavior of women of reproductive age in preconception care. The design of this study was a correlational study with a cross-sectional approach. Respondents of this study were 35 women of reproductive age who met the inclusion criteria and were collected by a simple random sampling technique. The variables of this research were the behavior of women of reproductive age and the factors that influence it in performing preconception care. The results showed that the behavior of women of reproductive age in performing care was in the range of occasional and frequent, factors that significantly related to the behavior of women of reproductive age in preconception care were the level of education, knowledge, attitudes, beliefs, and availability of infrastructure to carry out treatment preconception. Health cadres are expected to collaborate with the Public health Center to carry out counseling activities regularly to further increase their knowledge and awareness about the need for preconception care and the belief that pregnancy complications can be prevented through good care before pregnancy so that there is an increase in the behavior of women of reproductive age Pre-conception.
\end{abstract}

Keywords: preconception care, women of reproductive age

INTRODUCTION
One of the tasks of family
development is to reproduce or produce
offspring. The husband and wife certainly
hope to produce healthy offspring. The
health of the baby is not only determined
during pregnancy but also begins as far as
the time the parent prepares the pregnancy
itself(1)

\begin{abstract}
One effort that can be done to prepare for pregnancy is through preconception care. Pre-conception services include lifestyle changes, nutrition, general examination and examination of sexually transmitted diseases, and immunization. The purpose of preconception care is to ensure that the mother and her partner are in optimal physical and emotional health status at the onset of pregnancy and to determine
\end{abstract}


the extent to which women plan and prepare for pregnancy physically and emotionally optimally(2).

According to the 2016 National Population and Family Planning Agency (BKKBN) data, there are 4 million births each year and 14 percent of these births are unplanned pregnancies. In 2019, there are 14,4 percent of pregnancies in Jawa timur are unplanned pregnancy (3) In Indonesia, about $60 \%$ of women are infected with TORCH which causes congenital defects or deaths in 7-12 babies per 1000 births per year. About $5 \%$ of babies are born with defects, which can range from minor defects such as birthmarks (although this is not underestimated in mothers and infants) to abnormal life-threatening organs, such as the heart. Some records can be prevented, or the impact can be reduced through a healthy lifestyle before conception(4)

Based on the preliminary survey in one district in Surabaya showed that $80 \%$ of women of reproductive age in have not carried out general examinations, namely TORCH examination, an examination of sexually transmitted diseases (STDs), and examination of hereditary diseases because they do not know and understand preconceptions. They expressed that only knowing about fulfilling nutritional needs during preconception. A Lifestyle like smoking behavior is still done by the husband. Environment, public health, the fulfillment of nutritional needs during preconception, lack of understanding of the importance of conditions in the period before the conception process occurs.

Conditions that do not support preconception conditions will harm the formation of innate potential children, premature birth and low birth weight, congenital defects, and mental delay(5). A well-planned unplanned pregnancy and birth will result in death and various disease attacks, for example, hypertension Preeclampsia and eclampsia, namely chronic hypertension that occurs before pregnancy, obesity, close pregnancy intervals(6).
The purpose of this study was to identify the behavior of women of reproductive age in preconception care.

\section{METHOD}

The research design used in this study was cross-sectional observation in women of reproductive age in RT 1 \& RT 2 RW 6 Sawunggaling Village, Darmo District, Surabaya with inclusion criteria not using tubectomy contraception, aged 20-40 years, able to read and write and willing to be examined. The sample size taken in this study was 35 respondents collected by a simple random sampling technique.

Variable of this study were independent variables and dependent variable. Independent variables of this study were level of education, perception about pregnancy planning, preconception awareness, perception about preventive complications of pregnancy, availability of preconception facilities and preconception care information. Dependent variable of this study was preconception care behavior. Data were collected by questionnaire. The study used univariate analysis to present data characteristics of study subjects and descriptive of variables of the study. Bivariate analysis was used to analyze independent variables toward the dependent variable.

\section{RESULT}

Table 1. Characteristics of Respondents

\begin{tabular}{llll}
\hline Variable & n & \% & \\
\hline Age & & & \\
21-25 years old & 16 & 45,7 & Mean \\
26-30 years old & 14 & 40 & $26 \pm 4,1$ \\
31-35 years old & 3 & 8,6 & \\
>35 years old & 2 & 5,7 & \\
Education & & & \\
SMP & 14 & 11,4 & \\
SMA & 19 & 54,3 & \\
PT & 2 & 34,3 & \\
Perception & & & \\
about & & & \\
pregnancy & & & \\
planning & 33 & 94,3 & \\
Need & 2 & 5,7 & \\
No need & & &
\end{tabular}

No need 


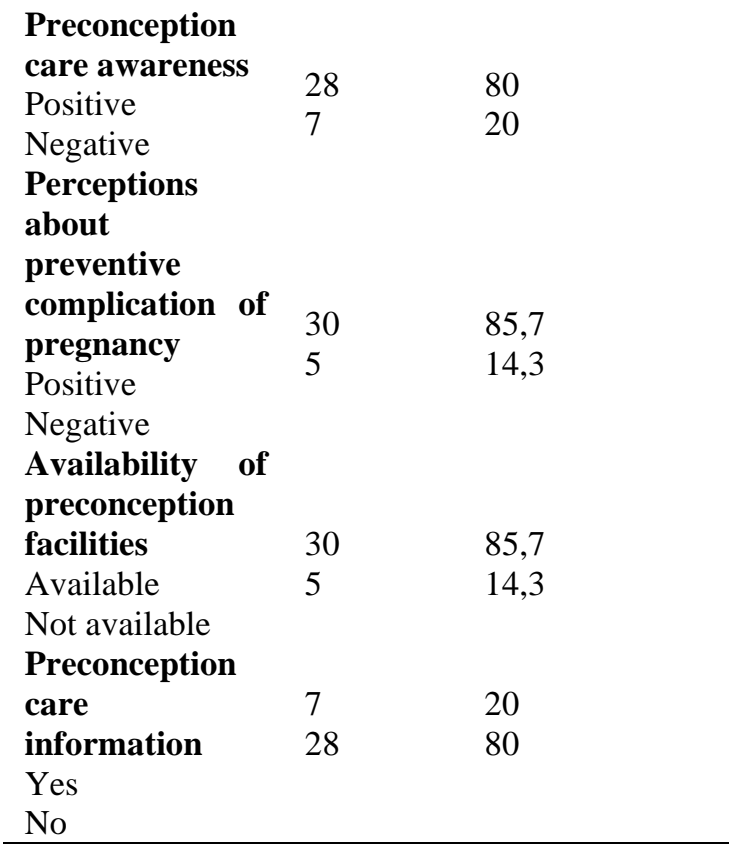

Table 1 showed the average age of respondents $26 \pm 4.1$ years, most education is high school $(54.3 \%), 94.3 \%$ of respondents have a perception that pregnancy needs to be planned, $80 \%$ of respondents expressed the need for preconception care measures, $85.7 \%$ of respondents have a perception that pregnancy complications can be prevented through preconception care, $85.7 \%$ of respondents stated that there were health facilities to get preconception care and $80 \%$ of respondents had never received information about preconception care.

Table 2. Women of reproductive age behavior in preconception care

\begin{tabular}{lll}
\hline Minimal & Maximal & Mean \\
\hline 1,5 & 4 & 2,55 \\
\hline
\end{tabular}

Behavior of women in preconception care practice was measured using likert scale, while score 1 meant never, 2 meant sometimes, 3 meant often and 4 meant always do preconception care. Table 2 showed that mean of preconception care behavior was 2,55. It meant that pre conception care behavior was in the range sometimes and often.
Tabel 3. Preconception aspects

\begin{tabular}{|c|c|}
\hline Preconception aspects & Mean \\
\hline Do pregnancy planning rightly & 2,68 \\
\hline Application of a healthy lifestyle & 2,91 \\
\hline $\begin{array}{l}\text { Fulfillment of preconception } \\
\text { nutritional needs }\end{array}$ & 2,61 \\
\hline General check-up before pregnancy & 2,3 \\
\hline $\begin{array}{l}\text { Preconception checks on dangerous } \\
\text { diseases Such as TORCH }\end{array}$ & 2,2 \\
\hline Immunization & 2,4 \\
\hline $\begin{array}{l}\text { Table } 3 \text { showed that the } \\
\text { frequently performed behavioral asp } \\
\text { preconception care are the adopt } \\
\text { healthy lifestyles and aspect } \\
\text { preconception care which were mos } \\
\text { not carried out by examining dan } \\
\text { diseases such as TORCH. }\end{array}$ & $\begin{array}{l}\text { most } \\
\text { ects in } \\
\text { ion of } \\
\text { s of } \\
\text { often } \\
\text { gerous }\end{array}$ \\
\hline
\end{tabular}

Tabel 4. Statistical test result

\begin{tabular}{|c|c|c|}
\hline Variable & $\mathrm{p}$ & \\
\hline Educational Status & 0,004 & Significant \\
\hline Knowledge & 0,00 & Significant \\
\hline $\begin{array}{l}\text { Awareness of the } \\
\text { importance of } \\
\text { preconception }\end{array}$ & 0,277 & $\begin{array}{l}\text { Not } \\
\text { significant }\end{array}$ \\
\hline $\begin{array}{l}\text { Perceptions about } \\
\text { preventive complication of } \\
\text { pregnancy }\end{array}$ & 0,028 & Significant \\
\hline $\begin{array}{l}\text { Availability of } \\
\text { preconception facilities }\end{array}$ & 0,04 & Significant \\
\hline $\begin{array}{l}\text { Preconception } \\
\text { information }\end{array}$ & 0,453 & $\begin{array}{l}\text { Not } \\
\text { significant }\end{array}$ \\
\hline
\end{tabular}

The results showed that the significant factors which corelate with the preconception care behavior were educational status, level of knowledge, perceptions about preventive complication of pregnancy and availability of pre conception facilities.

\section{DISCUSSION}

The purpose of preconception care is to ensure that the mother and her partner are in optimal physical and emotional health status during the onset of pregnancy, facilitating women to be healthy before she is pregnant so that babies are born healthy and optimal and provide possibilities best for babies to start life by minimizing risks related to lifestyle, heredity, medical history, and maternal age(2). Every fertile 
age couple is expected to take preconception care so they can have optimal physical and emotional readiness when entering conception. Through preconception care, the mother and partner can find out the things that support preparation during preconception. But the facts obtained from the results of the study, the behavior of respondents is only limited to sometimes often in preconception care. This shows the low awareness of the respondents to preconception care.

The results showed that the factors that significantly influence the preconception care behavior are education, knowledge, and respondents' beliefs that pregnancy complications can be prevented by preconception care, and the availability of means to conduct preconceptions. Lawrence Green's (1980) theory cited by Mubarak behavior is influenced by 3 factors, namely predisposing factors, Enabling Factors, and Reinforcing Factors. Predisposing factors (Predisposing Factors manifest in knowledge, attitudes, beliefs, beliefs, values, etc., Enabling Factors in the form of a physical environment (available or unavailability of health facilities or facilities)(7).

The researcher argues that the most dominant factor driving preconception care behavior by respondents is a predisposing factor in respondents' knowledge, attitudes, and beliefs that pregnancy complications can be prevented through good care before pregnancy.

The results showed that the level of education and knowledge about preconception care was significantly related to preconception care behavior. The education of the majority of respondents is secondary (SMP \& SMA). The higher a person's education makes it easier to receive and understand some information, and in the end, the knowledge they have will be gain. Conversely, if a person has a low level of education, it will hamper the development of the person's attitude towards receiving information and newly introduced values. Munthali-Nkoma (2021) concludes that educational level is associated with knowledge about preconception care(8). This is in line with Ayalew (2016) that a low level of education influences the awareness to carry out preconception care so that it affects the preconception care behavior(9). The results of this study are also in line with the research of Gund, Bhide, and Kar (2016) that knowledge influences the behavior of preconception care in Nepali women research and research (2017) a person's level of knowledge is significantly related to preconception care behavior(10). According to Nepali (2017), preconception care knowledge and behavior are significantly associated so that efforts need to be made to increase knowledge about preconception care to improve preconception care behavior(11).

The result also showed that respondent's Perceptions about a preventive complication of pregnancy were associated with preconception care. Respondents who rarely or even did preconception care generally argued that pregnancy was a natural process that did not need to be prepared specifically. This is in line with the research of Olowokere, Komolafe, and Owofadeju (2015) that awareness of the importance of preconception care affects the behavior of women of reproductive age in preconception care(12).

The results of the study show that the most frequently performed behavioral aspects in preconception care are the adoption of healthy lifestyles and aspects of preconception care that are most often not done are the examination of dangerous diseases such as TORCH. A healthy lifestyle is doing things that can improve health and avoid things that can endanger health and pregnancy. The healthy lifestyle patterns include avoiding smoking both as passive and active smokers, avoiding alcohol, exercising regularly, monitoring the body weight, and applying a balanced diet. The respondents applied a healthy lifestyle solely not only to prepare for pregnancy but also for health in general, so that the adoption of a healthy lifestyle is part of their 
daily lifestyle. This is different from examining dangerous diseases such as TORCH. Respondent's awareness of the importance of examining dangerous diseases is still low. This is in line with the research of Goosens et al (2017) that most women of reproductive age who carry out preconception treatments mostly make lifestyle changes in the form of adopting a healthy life(13).

\section{CONCLUSION}

Conclusions of this research are the behavior of women of reproductive age in pre-conception care is in the range of often and sometimes and factors related significantly to the behavior of women of reproductive age in preconception care are the level of education, knowledge, attitudes, beliefs, and availability of infrastructure to carry out preconception care.

\section{REFERENCE}

1. Riksani R. Tanya Jawab Seputar Kehamilan. Jakarta: Dunia Sehat; 2015.

2. Tharpe N., Farley C. Kapita Selekta Praktik Klinik Kebidanan. Jakarta: EGC; 2012.

3. Perwakilan BKKBN Provinsi Jawa Timur. Laporan Akuntabilitas Kinerja Instansi Pemerintah Perwakilan BKKBN Provinsi Jawa Timur Tahun 2019. 2020;47.

4. Mangkuji B, Ginting I, Suswaty, Lubis R, Wildan. Asuhan Kebidanan 7 Langkah. Jakarta: EGC; 2012.

5. Anggarani D., Dubakti Y. Kupas Tuntas Seputar kehamilan. Jakarta: PT. Agromedia Pustaka; 2013.

6. Triana A, Damayanti I., Afni R, Yanti J. Buku Ajar Kebidanan Kegawatdaruratan dan Neonatal. Yogyakarta: Deepublish; 2015.

7. Mubarak WI. Promosi Kesehatan Untuk Kebidanan. Jakarta: Salemba medika;
2012.

8. Munthali-Nkhoma M, Saul M, Mandiwa $\mathrm{C}$, Kazanga I. Knowledge and Perceptions of Preconception Care Among Health Workers and Women of Reproductive Age in Mzuzu City, Malawi. A Cross-sectional Study. Res $S q$ [Internet]. 2021;10:1-15. Available from: https://doi.org/10.21203/rs.3.rs$\underline{178037 / \mathrm{v} 1}$

9. Ayalew Y, Mulat A, Dile M, Simegn A. Women's knowledge and associated factors in preconception care in adet, west gojjam, northwest Ethiopia: A community based cross sectional study. Reprod Health [Internet]. 2017;14(1):110. Available from: http://dx.doi.org/10.1186/s12978-017$\underline{0279-4}$

10. Gund P, Bhide P. Prevalence of Periconception Risk Factors for Adverse Pregnancy Outcomes in a Cohort of Urban Indian Women: Implications for Preconception Health Education. J Womens Heal Care. 2016;05(01):1-5.

11. Nepali G, Sapkota SD. Knowledge and practice regarding preconception care among antenatal mothers. Int $J$ Perceptions Public Heal [Internet]. 2017;1(4):224-7. Available from: https://www.researchgate.net/publicatio $\underline{\mathrm{n} / 319490058}$

12. Olowokere A., Komolafe A, Owofadeju C. Awareness knowledge and uptake of preconception care among women in Ife Central Local Government Area of Osun State Nigeria. J Community Med Prim Heal Care. 2015;27(2):83-92.

13. Goossens J, Beeckman D, Van Hecke A, Delbaere I, Verhaeghe S. Preconception lifestyle changes in women with planned pregnancies. Midwifery [Internet]. 2018 Jan 1 [cited 2019 Jul 31];56:112-20. Available from: 
http://www.ncbi.nlm.nih.gov/pubmed/29

096279 